\title{
Investigation of Students' Alternative Conceptions of Terms and Processes of Gene Technology
}

\author{
Gaitano Franke, Franz-Josef Scharfenberg, and Franz X. Bogner \\ Department of Biology Didactics, University of Bayreuth, University Campus/NW I, 95447 Bayreuth, Germany
}

Correspondence should be addressed to Gaitano Franke; gaitano.franke@uni-bayreuth.de

Received 8 February 2013; Accepted 18 March 2013

Academic Editors: L. Lavelle and M. J. Raddick

Copyright (C) 2013 Gaitano Franke et al. This is an open access article distributed under the Creative Commons Attribution License, which permits unrestricted use, distribution, and reproduction in any medium, provided the original work is properly cited.

\begin{abstract}
Our study monitored students' alternative conceptions about some fundamental terms and processes of gene technology. Novice secondary school 10th graders (144 in total) described their conceptions in an open questionnaire. Using inductive category development, we iteratively categorized their responses. We found 13 categories describing students' conceptions. Common categories were allocated to more than one different term or process. Specific categories were found only in the context of explaining one term or process. Using the collected conceptions, we then developed a questionnaire, which we administered to monitor the students' conceptual change during a hands-on approach in our outreach lab. Knowledge about these conceptions and their consideration within science teaching should be of value both for preservice teacher education and for professional development of in-service teachers.
\end{abstract}

\section{Introduction}

Based on everyday experience, students have their own conceptions on different subjects of science education, and they bring these conceptions along to the classroom (e.g., [1]). Within the literature, there are many terms for students' own conceptions, such as preconceptions [2], alternative conceptions [3], misconceptions [4], alternative frameworks [5], common-sense concepts [6], initial conceptions [7], or everyday conceptions [8]. Within this paper, we use alternative conceptions as a neutral term for labeling students' conceptions.

Students' alternative conceptions are based on "personal experiences" [9, page 1158] and, especially in the area of genetics, are influenced by the students' social environment [10]. Often they differ from "those generally accepted by the scientific community" [11, page 159]. This discrepancy may prevent students from understanding a taught scientific concept. Thus, students must change their alternative conceptions and reconstruct their knowledge towards the new "to-be-learned" conception [7, page 27], within genetics education especially by using reasoning processes [12]. The consideration of students' alternative conceptions within teaching is a prerequisite for such a conceptual change $[13,14]$.
The acceptance of a to-be-learned scientific conception seems only possible when existing individual alternative conceptions and scientific ones are simultaneously acknowledged in order to prompt a cognitive conflict. To achieve this, Posner et al. [13] noted four conditions: (a) a currently held conception does not satisfy the learner; (b) any newly provided conception must be intelligible; (c) the learner must regard the new conception as plausible; (d) the new conception should lead to a fruitful research agenda. Nevertheless, the adoption of a to-be-learned conception does not occur suddenly but rather follows a slow, continuous learning process [15], also described as "conceptual reconstruction" [16, page 122]. Especially with regard to the scientific conception of the gene, Venville and Treagust [17, page 1052] found an "evolutionary process" in which the "previous (alternative) conceptions are reconciled with the new (scientific) conceptions."

A potential practical way of coping with conceptual change in a classroom may lie in the theoretical Model of Educational Reconstruction (e.g., [18]). Within this framework, teaching "is not mainly or even solely oriented to scientific issues but includes (...) students' conceptions as well" [19, page 341] in order to bridge the gap between a science subject matter and students' respective alternative conceptions [20]. As a consequence, the model takes three 
components into account: the analyses of the science subject, the investigation of the students' conceptions, and designinglearning activities based on the "results from the previous two components" [21, page 925]. Thus, applying of the model involves determining students' alternative conceptions and subsequently considering the revealed conceptions in teaching approaches. A suitable teaching strategy might be to present alternative conceptions on the basis of the constructivist teaching sequence $[22,23]$. The first phase (orientation) is followed by a discovery phase of the students' conceptions (elicitation of ideas), and a subsequent restructuring phase of the selected conceptions (restructuring of ideas) follows. During these phases, a process of clarification and exchange takes place, where single conceptions are put in conflict with each other to allow the construction of new conceptions. These phases are followed by the application of the new conceptions (application of ideas) as well as by an assessment of the changes which may have resulted (review of change in ideas). The consequent comparison of the new and old conceptions concludes the constructive teaching sequence.

Primarily, the Model of Educational Reconstruction was developed and empirically employed within physics education (e.g., teaching chaos theory; [19]), followed by applications within biology education research (e.g., teaching cell biology; [24]). Implementing teaching approaches, such as the constructive teaching sequence, based on this model may improve students' learning, because students regard scientific content as significant when their own conceptions are met (e.g., [10]). Therefore, integrating the students' alternative conceptions as revealed by science education into teaching enhancement approaches and subsequently into teacher training programs may eventually lead to this theoretical model being practiced more often.

According to Chi et al. [7], the meaning of a conception can be determined by a categorization, that is, the assignment to one or more categories within a system of categories. For a successful implementation of students' alternative conceptions within teaching practice, such a categorization is necessary, coupled with an interpretation of the results found therein.

Within various subject areas, researchers have been gathering students' alternative conceptions, summarized within the Pupils' and Teachers' Conceptions and Science Education database [25]. Nevertheless, the field of research into alternative conceptions within biology education is still emerging [1]. Despite rapid advances in genetics research, this may especially prove true in the field of genetics education where only several studies have already been published.

For the most part, only qualitative studies have been published. Authors have usually employed problem-centered semistructured interviews (e.g., $[8,26]$ ) and in one case, transcript analyses of videotaped lessons [27]. Both methodologies have been coupled with qualitative content analysis. For instance regarding Australian students aged 9 to 15 years, Venville et al. [26, page 628] found that "most students ... did not have a conceptual understanding of what genes ... are or what they do." Especially, "their understandings about kinship and inheritance could not be considered a theory of genetics" (page 628). According to Springer [28], students first acquire a theory of kinship that differentiates the culturally passed on and/or learned traits from genetically the inherited traits, but at this stage they cannot explain the underlying mechanisms. Additionally, Nelkin and Lindee [29, page 198] suggested a cultural anticipation in Western culture that genes as "key to human relationship" connect parents with offspring. Therefore, genes are regarded as a "metaphor for relationship" which "reinforces" this primary nongenetic understanding [26, page 629]. In contrast, Lewis and Kattmann [8, page 195] found that older German students (aged 15-19) have an alternative conception of genes as "small trait-bearing particles." Furthermore, there was "no clear distinction between genotype and phenotype."

The small sample size of the descriptive studies outlined above makes it difficult to draw general conclusions about student learning. But up to now, only a few quantitative studies have been published. For instance, Venville and Treagust [17] described a case study for Australian 10th graders, focusing on the terms genes, chromosomes, and Deoxyribonucleic acid (DNA). After scrutinizing the students' knowledge for their conceptions regarding those terms, they found 26 conceptions, such as "genes are passed from parents to offspring" [17, page 1038]. Lewis et al. [30] analyzed a knowledge questionnaire with regard to "biological terms" like genes or genetic information, assessing English students aged 14-16. Despite the students' previous genetic education, they found that they lacked an understanding of "function, structure, and location of genes" [30, page 74]. After reanalyzing this data set, Lewis and Kattmann [8] also reported the aforementioned alternative conception of genes as small particles. Analyzing written assessments, Duncan and Reiser [31] identified 15 conceptions of the term gene and of geneprotein connections, for instance, "genes as passive particles" that "determine the structure/behavior of proteins" [31, pages 945 and 948]. Recently, Duncan et al. [32] reported that students as young as 7 th graders have the conception of the term gene as a passive but determining particle. The authors summarize these conceptions as "non-information based views of genes" based on the students' conceptions lacking the connection to hereditary information (page 156). Finally, Mills Shaw et al. [9] analyzed essays from a knowledge essay contest of 12th graders in the US with regard to alternative conceptions. In total, they reported 27 conceptions of genetics content, for instance, "genes determine all traits" [9, page 1161]. With regard to gene technology, Mills Shaw et al. [9, page 1164] reported that their 12th graders coupled "genetic technologies" at the phenotypic level primarily to "curing multiple diseases" as well as to a trait expressed in the original manner after a gene transfer to a target organism.

In summary, up to now, quantitative research with regard to students' alternative conceptions within genetics education has focused on student conception data which have indirectly been gathered out of knowledge assessments. That is, the students have implicitly and unknowingly described their conceptions within their knowledge tests. A potential drawback of this methodology is that the authors did not report any data about specific combinations of students' alternative conceptions even though such combinations might exist. For instance, Duncan and Reiser [31] briefly mentioned 
"that a few" of their 63 students "made reference to more than one" conception [31, page 948]. Similarly, Tsui and Treagust [33, page 212] found "that a student could hold more than one gene conception." However, both studies lacked further analyses. Additionally, nearly all the aforementioned studies unfortunately did not present data with regard to the objectivity of the categorization applied (except [32]). Finally, gene technology, which plays a prominent role within genetics, was generally not included.

Keeping this in mind, we devised our first three research questions: (a) which alternative conceptions (inductively categorized) in the context of gene technology do students explicitly describe? (b) How frequently do these conceptions appear? (c) Are any specific combinations of the conceptions present?

Using the research results about students' alternative conceptions has often been shown to lead to successful lessons. Such intervention studies are frequent in different areas of science education and have been summarized within the Pupils' and Teachers' Conceptions and Science Education database [25]. For instance, the database includes studies in mechanics [34], in chemistry (e.g., [35]), or in evolution (e.g., [36]).

Regarding genetics, there have been a number of studies (e.g., [17, 27, 31-33, 37, 38]). For instance, Tsui and Treagust [33] reported that most of their participating 10th and 12th graders improved their genetic reasoning when "teachers included computer multimedia" in their classroom teaching. Especially, "multiple representations supported conceptual understanding of genetics" (page 205). Similarly, Mbajiorgu et al. [37] successfully applied "models and external representations" to dissatisfy students (aged 17 to 18 years) with their nonscientific religious presuppositions about genetic phenomena. Duncan et al. [32] recently reported that students as young as 7 th graders might have developed genetic reasoning at the molecular level, after the instructors taught a model-based unit which included "3D images" (page 152). Finally, Stolarsky Ben-Nun and Yarden analyzed the changes in 12th graders' conceptions with regard to molecular genetics caused by "hands-on experiences" in a teacher-led outreach laboratory "in which the high school teacher teaches his or her own students" (page 25). Based on true/false statements, they found that the students' "visual representations of DNA and plasmid significantly improved following the activity" (page 22). However, a potential methodological drawback of all studies reported here (except for [37]) is that researchers did not apply a control group design. To best of our knowledge, there has been no intervention study to date on the issue of gene technology which compares a group instructed using an approach potentially fostering conceptual change with a corresponding control group without this treatment. Additionally as mentioned above, quantitative research with regard to students' alternative conceptions within genetics education has only focused on conceptions which students have implicitly and unknowingly described. Based on these considerations, we devised our fourth research question: how can the results of the research based on our first three questions be used to evaluate a teaching approach to elicit conceptual change in the area of gene technology with a control group design? The research results addressing our first three research questions should identify any inductively categorized conceptions in the context of gene technology, indicate how frequently these conceptions appear, and determine the presence of any specific conception combinations. We hypothesize that such knowledge would be a good basis for a questionnaire evaluating any conceptual change from the students' alternative to the scientific conceptions. In particular, analyzing the students' answers to such a questionnaire could better indicate whether the scientific conceptions would have been learned if the alternative conceptions included in the questionnaire as distractors were collected from this very target group prior to the following planned interventional approach up to now; only Mbajiorgu et al. [37] have applied such a method. Before their intervention, the authors gathered the specific religious and cultural presuppositions of their Igbo tribal students (Nigeria). The presuppositions were gathered by analyzing students' written responses to genetic phenomena case studies. In contrast, Stolarsky Ben-Nun and Yarden [27] did not describe how they developed their true/false questionnaire mentioned above. Consequently, we decided to use the knowledge gained from answering our first three research questions regarding students' held alternative conceptions to develop a questionnaire for evaluating the efficiency of a new hands-on approach in our outreach laboratory designed to foster conceptual change.

To describe the contextual background of our study, we first provide information about the educational system in Bavaria, Germany. Second we describe biology education with respect to gene technology at the different stratification levels. Third, we present a short description of our new instructional approach for facilitating conceptual change in our outreach lab. Finally, we finish with the objectives of our study.

In Bavaria, Germany, students enter a secondary school (by their own and/or their parents' choice) as 5th graders at one of the three different stratification levels: the Gymnasium as a "university-preparatory secondary school" (highest level; up to the 12th grade); the Realschule as a "professionally oriented secondary school," where students may receive the "intermediate secondary school-leaving certificate" (intermediate level, up to the 10th grade); the Hauptschule as a "vocationally oriented secondary school for non-university bound students" (lowest level, up to the 9th grade; [39, page 1]). In 2009, 23\% of the Bavarian students graduated from the highest level of secondary school, $49 \%$ from the intermediate, and $33 \%$ from the lowest level [40]. Thus, we chose the intermediate level as the target group of our research because most students finished education at this level.

Within biology education, the subject of gene technology (in German Gentechnik) is a required subject specified in the current Bavarian syllabuses. However, the three levels differ with regard to how gene technology is taught: at the lowest level, 9th graders only get a general idea of gene technology (overview of applications and chances; [41]); at the intermediate level, 10th graders gain basic knowledge about gene technology, including one principle of changing genes as well as information about possibilities and potential risks [42]; 
at the highest level, biology education provides 11th graders with advanced knowledge, including recent developments (e.g., gene therapy; [43]). Based on the syllabus of our target group, we decided to focus on students' alternative conceptions of fundamental terms (gene, genetic engineering, clone, and enzyme) and processes (inheritance of traits, transfer of genes, and change of genotype) in the context of gene technology. We chose an approach that combined both qualitative and quantitative aspects in order to develop a questionnaire for evaluating the efficiency of our new hands-on approach in our outreach laboratory, shortly described below, and to obtain recommendations for in-service teacher professional development as well as preservice teacher education. On the basis of our survey, teachers and teacher educators would be able to focus on both common and rare alternative conceptions.

For teaching gene technology, we developed a teaching unit, which concentrated on specific learning goals within the current syllabus, for instance, the ability to carry out gene technology experiments in small groups and receiving an overview about the principles of gene technology. The learning unit took place in our out-of-school laboratory due to time and resource limitations at school. The lessons consisted of a 60-min pre-lab phase and a 300-min experimental-lab phase. In the pre-lab phase, the students were introduced to the basic operations at their work area, such as correctly using a micropipette or working sterilely. A pre-lab phase is necessary to ensure the safe execution of the subsequent experimental-lab phase (e.g., [44]). In the experimentallab phase, the students carried out four gene technology experiments: (a) the enzymatic restriction of plasmid DNA with two selected enzymes, (b) the ligation of DNA, (c) the transformation of bacteria with recombinant plasmids, and (d) the inoculation of the bacterial samples on agar plates. For fostering conceptual change in students learning gene technology, we chose the constructivist teaching sequence [22] mentioned above. This approach begins by confronting the students with different alternative conceptions followed by presenting the contradictory scientific view. We decided to use examples of students' alternative conceptions from our present survey. For evaluating the efficiency of our approach, we compared this instructional mode (in a treatment group) with a conventional approach that does not explicitly consider students' alternative conceptions (in a control group). The results of this main study have been published elsewhere [45]. Here we will report on the development of the questionnaire measuring conceptual change, which was based on our present survey, and the specific results of the students, who took part in the study as a whole, comprising a subsample of the students in our main study.

In summary, the objectives of our present study were (a) to gather students' alternative conceptions in the context of gene technology by prompting the students to explicitly describe their conceptions; (b) to inductively categorize students' conceptions; (c) to analyze the frequencies of the categories found, especially with regard to any conspicuous combinations of categories; (d) to develop and evaluate a questionnaire for measuring conceptual change, based on the knowledge gained by meeting the first three objectives.

\section{Methodology}

2.1. The Participants. We selected students at the intermediate stratification level of secondary school (Bavarian Realschule) at start of 10th grade. Altogether, five classes of students $(N=$ 144) participated in the study (69 boys, 75 girls, age: $M=$ $15.6, \mathrm{SD}=0.70)$. All students were novices in gene technology. Before participation in the study, they did not have any lesson yet in genetic education at school. One of these classes later participated in our main study as a treatment group class $(n=25)$. Unfortunately, the remaining four classes could not take part in the lessons for organizational reasons.

2.2. The Measures. We administered an open questionnaire with seven items to be answered in about $30 \mathrm{~min}$ (see Table 5). Students were prompted to explicitly describe their conceptions about specific terms of gene technology (four items: gene, genetic engineering, clone, and enzyme) as well as about gene technology processes (three items: the inheritance of traits, the transfer of genes, and the change of genotype).

We iteratively categorized the students' descriptions by following the method of inductive category development [46] and subsequently assigned 13 categories (see Tables 1, 3, and 6).

We pretrained two categorizers who used set guidelines to jointly categorize the first questionnaires. Based on randomly selected descriptions from $10 \%$ of the participants, we assessed the intra- and interrater reliabilities with Cohen's coefficient Kappa: intrarater reliability $\kappa=0.86$; interrater reliability $\kappa=0.72$ [47], which can be rated as "substantial" to "almost perfect" [48, page 964].

Based on the categorization and the frequencies revealed thus far, we selected three descriptions for each term and each process of gene technology. All the descriptions were from different students. We combined these descriptions for use as distractors with the correct scientific conception for use as the "key" of each item (e.g., [49, page 3]) in a seven-item multiple choice questionnaire (see Table 8, details described below). Thus, the questionnaire comprised all terms and processes of gene technology based on the obtained student alternative conceptions. We administered the questionnaire three times to the subsample of students described above who took part in our main study half a year after our survey. The students completed the questionnaire for the first time one week before the hands-on lesson in the lab, the second time immediately after the lab lesson, and the third time six weeks later. We have described this methodology in detail in our published main study [45].

\section{Results}

In the following, we first present all the categories we found. Then, we describe the category frequencies. Next, we describe the categories most often indicated by the students. Finally, we present the conceptual change questionnaire developed and the results of its administration to the subsample who took part on our gene technology hands-on unit. 
TABLE 1: Common categories of students' conceptions, each category with one sample term and one sample process of gene technology (students' key words for each category are within students' quotations in italic letters; see Table 6 for all categories).

\begin{tabular}{|c|c|c|c|}
\hline \multirow{2}{*}{ Category } & \multirow{2}{*}{$\begin{array}{l}\text { Definition: } \\
\text { conception is connected to ... }\end{array}$} & \multicolumn{2}{|c|}{ Students' application to the } \\
\hline & & term of gene $e^{a}$ & process of change of genotype $\mathrm{a}^{\mathrm{a}}$ \\
\hline Genotype & Genotypic level. & ... means genetic information ... & $\begin{array}{l}\text {... means that hereditary information will be } \\
\text { changed. }\end{array}$ \\
\hline Phenotype & Phenotypic level. & $\ldots$ which eye color one has, ... & $\begin{array}{l}\ldots \text { is the chemical change of certain traits of the } \\
\text { father. }\end{array}$ \\
\hline Procedure & Techniques and/or equipment. & & $\begin{array}{l}\text {.. means that parts of the genotype are changed by } \\
\text { medical techniques. }\end{array}$ \\
\hline Pedigree & Words showing relationships. & $\begin{array}{l}\text { The child of a pair has the genes } \\
\text { of his/her parents ... }\end{array}$ & $\begin{array}{l}\text { For example, if everybody in the family has blond } \\
\text { hair and one child has red hair. }\end{array}$ \\
\hline Valuation & Value-related aspects. & & $\ldots$ is a specific manipulation. \\
\hline Object & A specific object. & $\ldots$ are small cells... & If one changes the genes of a human being. \\
\hline Localization & A specific localization. & ... inside of the person ... & \\
\hline
\end{tabular}

${ }^{\mathrm{a}}$ Sample student quotation.

TABLE 2: Common categories of students' conceptions about the terms and processes of gene technology.

\begin{tabular}{|c|c|c|c|c|c|c|c|}
\hline \multirow[b]{2}{*}{ Category } & \multicolumn{7}{|c|}{ Students' application to the } \\
\hline & gene & $\begin{array}{l}\text { terms of } \\
\text { genetic engineering }\end{array}$ & clone & enzyme & inheritance of traits & $\begin{array}{c}\text { processes of } \\
\text { transfer of genes }\end{array}$ & change of genotype \\
\hline Genotype & + & + & + & & + & & + \\
\hline Phenotype & + & + & + & & + & + & + \\
\hline Procedure & & + & + & & + & + & + \\
\hline Pedigree & + & & & & + & + & + \\
\hline Valuation & & + & + & & & & + \\
\hline Object & + & & + & + & & & + \\
\hline Localization & + & & & + & & & \\
\hline
\end{tabular}

+ shows occurrence of the category with regard to the given term or process.

TABLE 3: Specific categories of students' conceptions about the terms and processes of gene technology (students' key words for each category within students' quotations in italic letters).

\begin{tabular}{lll}
\hline Category & Definition: connection to ... & Students' application to the \\
\hline $\begin{array}{l}\text { Container } \\
\text { Transmission }\end{array}$ & A container with something inside & Term of gene $^{\mathrm{a}}$ \\
Individuality & Something which is transmitted. & A "cell" with certain traits inside. \\
& A unique specificity of genes. & Genes will betransmitted. \\
\hline $\begin{array}{l}\text { Function } \\
\text { Source }\end{array}$ & Specific functions. & A gene is the individual code of every living being. \\
\hline & Uptake from a source. & Term of enzyme \\
\hline Science & & $\ldots$ are illness-restraining substances. \\
& Science or scientific approaches. & $\ldots$ are taken up by food. \\
\hline
\end{tabular}

${ }^{a}$ Sample student quotation.

3.1. Categorization of Students' Alternative Conceptions in the Context of Gene Technology. In total, we extracted 13 different categories of conceptions, which we subsequently classified into two main groups. One group comprises categories which we found within at least two descriptions of conceptions regarding the different terms or processes, which we labeled as common categories: phenotype, genotype, procedure, pedigree, object, valuation, and localization. Table 1 shows these categories along with their definitions and examples of students' quotations; Table 2 summarizes the connection of these categories to the terms and processes (for details, see Table 6). The second group comprises categories which we 


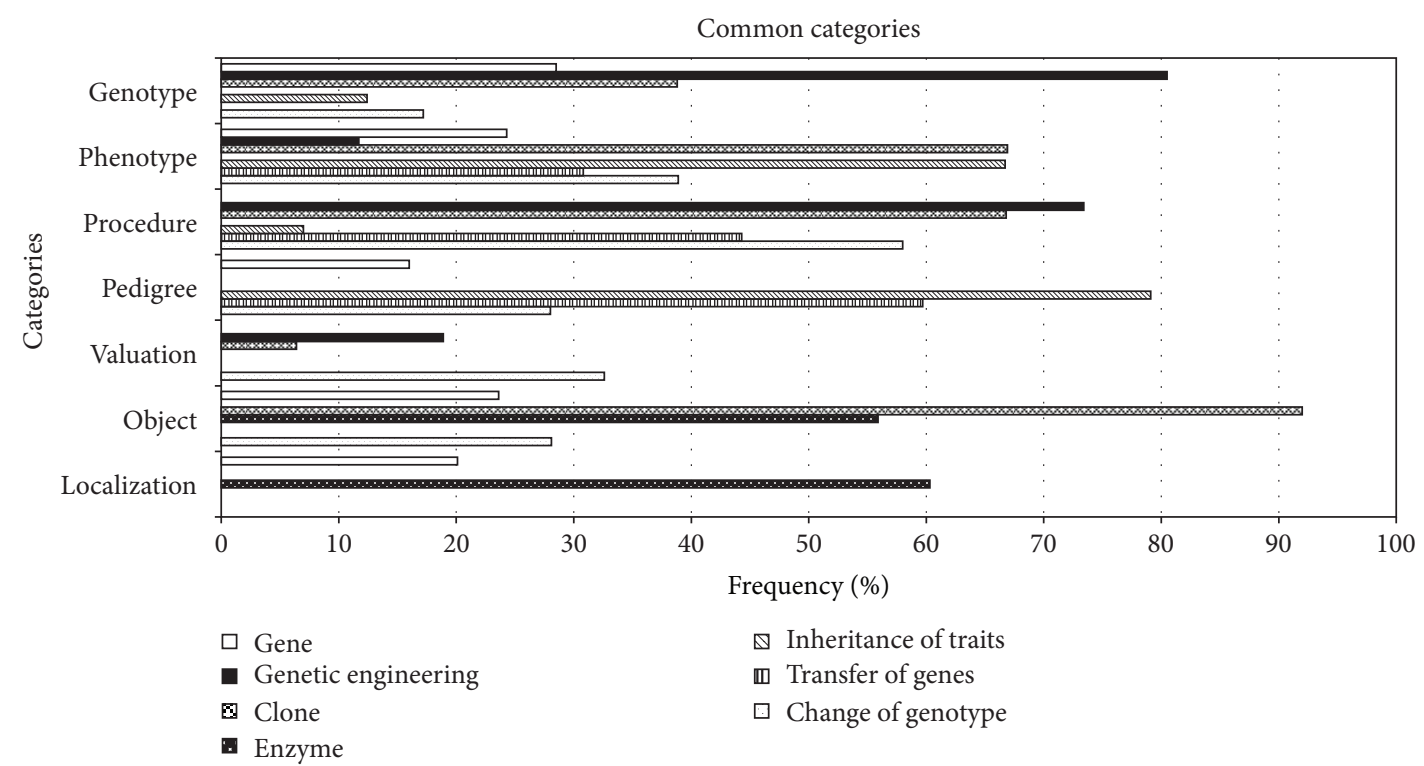

FIGURE 1: Common category frequencies in students' conceptions with regard to the terms and processes of gene technology (multiple terms possible), see Table 6).

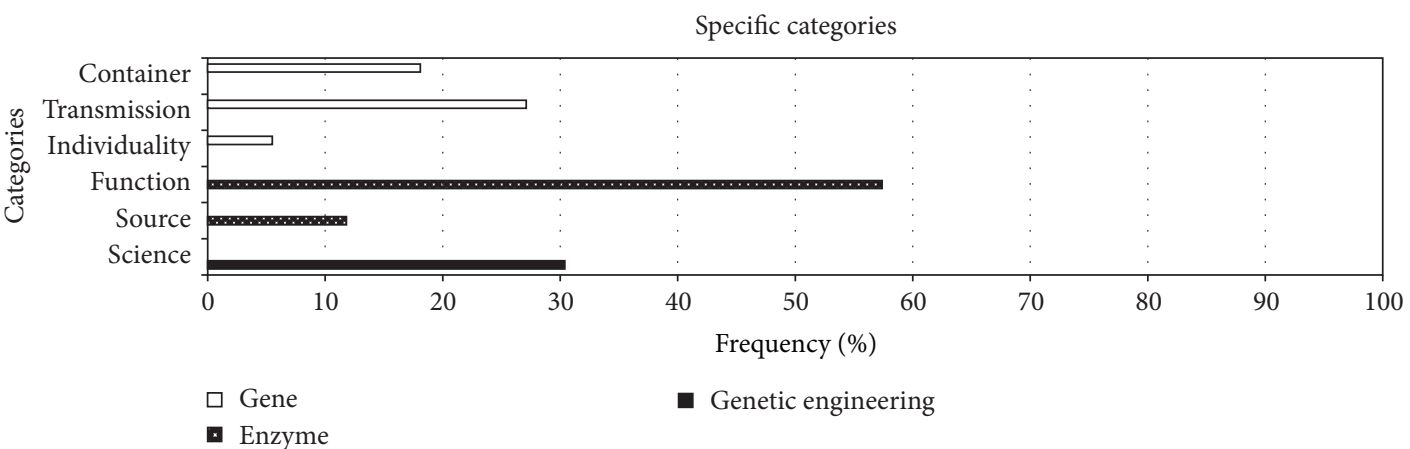

FIGURE 2: Specific category frequencies in students' conceptions with regard to the terms gene, enzyme, and genetic engineering (multiple terms possible).

just found within students' conceptions of only one term or process, which we labeled as specific categories (see Table 3): container, transmission, and individuality (the term gene); function and source (the term enzyme); and science (the process genetic engineering). The number of the categories yielded per term or process ranged from three (e.g., for the process transfer of genes) to seven (e.g., for the term gene).

3.2. Frequencies of the Identified Categories. Subsequently, we calculated the frequencies of the categorized conceptions for the common (see Figure 1, Table 7) and the specific categories (see Figure 2, Table 7).

Regarding the frequencies of the described conceptions, some students described more than one conception per term or process (see Table 4) while some students did not provide any suitable conception (see Table 4 , notes from b to $h$ ); in the case of the term enzyme, up to $52.8 \%$ failed to provide a suitable conception. However, for the term clone, nearly every student provided at least one conception (96.5\%). In the cases of the terms genetic engineering and clone as well as of the process change of genotype, up to five different conceptions were provided by some students.

3.3. Commonly Obtained Student Categories Regarding the Terms and Processes of Gene Technology. In the following, we describe those categories (including examples of students' quotations), which were commonly obtained from students' descriptions of their conceptions, either as solitary categories or in combination. The bracketed numbers show the frequencies of all the students' conceptions (in percent).

(a) Gene. Most of the conceptions belonged to the category object $(10.4 \%)$, with no reference to another category. Some students combined the categories genotype and container within their descriptions (9.7\%), for instance, "that's a sort of cell with hereditary information inside". 
TABLE 4: Coupling of students' conceptions to the different terms and processes of gene technology.

\begin{tabular}{|c|c|c|c|c|c|}
\hline \multirow{2}{*}{ Conceptions about ... } & \multicolumn{5}{|c|}{ Frequency of coupled student conceptions (percentage) } \\
\hline & None $\mathrm{a}^{\mathrm{a}}$ & Two & Three & Four & Five \\
\hline Gene $^{b}$ & 32.6 & 38.9 & 11.8 & 3.5 & - \\
\hline Genetic engineering $^{c}$ & 12.5 & 43.1 & 18.1 & 2.8 & 1.4 \\
\hline Clone $^{\mathrm{d}}$ & 6.3 & 29.9 & 41.0 & 18.8 & 0.7 \\
\hline Enzyme $^{\mathrm{e}}$ & 18.8 & 18.8 & 6.9 & 2.8 & - \\
\hline Inheritance of traits ${ }^{\mathrm{f}}$ & 34.7 & 52.1 & 3.5 & - & - \\
\hline Transfer of genes ${ }^{\mathrm{g}}$ & 28.5 & 29.2 & 12.5 & - & - \\
\hline Change of genotype $\mathrm{h}^{\mathrm{h}}$ & 32.6 & 27.8 & 13.2 & 2.8 & 0.7 \\
\hline
\end{tabular}

${ }^{a}$ Proportion of students that described only one conception; ${ }^{b}$ to ${ }^{\mathrm{h}}$ frequency of students describing no conceptions: ${ }^{\mathrm{b}} 13.2 \%$; ${ }^{\mathrm{c}} 22.2 \%$; ${ }^{\mathrm{d}} 3.5 \%$; ${ }^{\mathrm{e}} 52.8 \%$; ${ }^{\mathrm{f}} 9.7 \%$; $\mathrm{g}_{29.9 \%}$; ${ }^{\mathrm{h}} 22.9 \%$.

TABLE 5: Questionnaire about students' conceptions in gene technology.

\begin{tabular}{ll}
\hline No. Item \\
\hline (1) What are your conceptions with regard to the term gene? \\
(2) What are your conceptions with regard to the term genetic \\
(3) What are your conceptions with regard to the term clone? \\
(4) What are your conceptions with regard to the term \\
(5) What are your conceptions with regard to the process \\
inheritance of traits? \\
(6) What are your conceptions with regard to the process \\
(7) What are your conceptions with regard to the process \\
\hline
\end{tabular}

(b) Genetic Engineering. Many students used a combination of the categories genotype and procedure (31.9\%), for instance, "possibility of changing genes by using technical equipment." Some added category science $(6.9 \%)$, for instance, "specific science which transfers genes from one individual to another thereby creating a new sort of being."

(c) Clone. These conceptions were described either with a combination of the categories object and phenotype (11.1\%), for example, "clones are the exact copy of living beings, they have the same genetic fingerprint" or with a combination of the categories object and genotype (10.4\%), such as "clones are two human beings with identical genes." However, most students used a combination of three categories: object, phenotype, and procedure (31.9\%), for instance, "a clone is a human being who has been copied and looks like the original one". Additionally, there were students who combined the four categories object, phenotype, procedure, and genotype (10.4\%), for instance, "a clone is a human being or another organism which has been copied exactly and includes the same genes and heredity information." (d) Enzyme. For this term, most students had no conceptions, resulting in the fewest categories chosen in terms of percentage (see Table 4). Students especially used the categories localization or function $(6.9 \%$ or $7.6 \%$ ) or a combination of both $(7.6 \%)$, such as "enzymes are part of our body; they take care of many different things". Others combined the categories object and function (6.3\%), for example, "enzymes are particles which destroy organic materials" or even the categories object, function, and localization (6.9\%): "a corpuscle within a being, which protects against specific diseases".

(e) Processes. Conceptions of the process inheritance of traits exclusively employed the categories phenotype (13.2\%), pedigree $(17.4 \%)$, or a combination of both (44.4\%), for instance, "I have the same sort of laughter as my mother". The students' conception of the process transfer of genes can be assigned to the categories procedure $(23.6 \%)$ or pedigree $(18.8 \%)$. If two categories were used at the same time, the combination of phenotype and pedigree was most frequent (16\%), such as "when a man's and a woman's traits are transferred to their child." A clear picture arose with regard to the process change of genotype where students primarily used the category procedure (13.9\%). A combination of several categories was often observed (43.5\%, see Table 4 ), but no combination of categories was more often than others.

3.4. Development of a Questionnaire Measuring Conceptual Change in the Context of Gene Technology. As mentioned above, we combined the descriptions of students' alternative conceptions (as distractors) with the correct scientific conception (as the key for each item) to a seven-item multiple choice questionnaire (see Table 8). As usual, we started each item with a stem (e.g., [49]) which introduced the term or process being asked for. Generally, we selected short student's sentences for the distractors. As an example, we describe item one, which asks for students' conception about the term gene. Beside the correct statement (by a gene, I understand a hereditary factor, for instance, for the color of hair), we 
selected the following student's statements as the three distractors. First, by a gene, I understand (a) a trait, for instance, for the color of hair. This description provided the category phenotype as a single category, based on our result that about a quarter of the students assigned this category to the term gene, and consequently had problems differentiating between the phenotypic and the genotypic level (see Table 7). Second, by a gene, I understand (b) a bacterium that transfers traits, for instance, the color of hairs. This student's statement again comprised the category phenotype. However, the student combined it with the category object, which was the most common category if student's responses included only one category, and the specific category transmission, which only appeared with regard to the term gene. And third, by a gene, I understand (c) a cell that contains hereditary factors, for instance, for the color of hairs. This student's description again comprised the category object but combined with the categories genotype and container, which was one of the commonly found combinations, as mentioned above. Additionally, the category container was a specific category for the term gene. Similarly, the questionnaire comprised all of the students' alternative conceptions regarding all the terms and processes of gene technology (see Table 8).

3.5. Evaluation of Conceptual Change. As mentioned above, a subsample of our students took part in the instructional treatment of our main study in which the constructivist teaching sequence was used employing the collected alternative conceptions of the present study. The students of this subsample significantly changed their conceptions over the three test dates: pre-, post-, and retention test (Friedman test: $\left.\chi^{2}=6.36 ; P=.036\right)$. They relinquished some alternative conceptions in favor of more scientific conceptions (see Figure 3 and Table 9).

That is, this subsample of our treatment group identically behaved as the treatment group of our main study as a whole. Students of the group as a whole gave up more alternative conceptions in favor of the scientific views. Their conceptual change was especially effective in the long term. However, control group students not exposed to this approach also changed some conceptions, but only in the short term (for details, see [45]).

\section{Discussion}

The main purpose of our study concentrated on qualitative and quantitative investigation of students' explicitly written conceptions to terms and processes within the context of gene technology. Based on the collected conceptions, we developed a questionnaire for measuring conceptual change. We administered it to a subsample of our students, providing a treatment group with a constructivist teaching sequence, again using the previously collected conceptions. In the following, we discuss our results first with regard to the methodological aspects. Second, we discuss the conceptual aspects with respect to our categories and to term- or processspecific aspects. Finally, we consider the evaluation results.

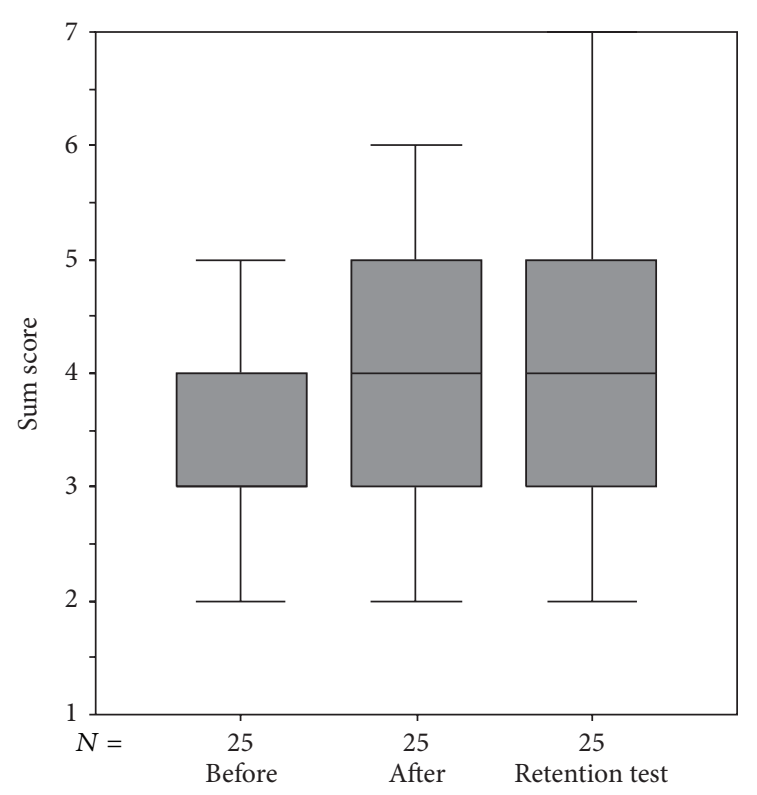

FIgUre 3: Changes in the scientific conception sum scores of the subsample who took part our constructivist teaching sequence approach over all three test schedules.

4.1. Methodological Aspects. Methodologically, we first considered the validity of our measurement. Within our results, we found conceptions previously known to be held by students with ages similar to those of our students. For instance, Kattmann et al. [50] reported that students mostly used the phenotypic level to explain the term gene, while some of them even equated genes and traits. In our case, the category phenotype was especially apparent in students' conceptions of the processes inheritance of traits and change of genotype. Thus, the assignment of these processes to the genotypic or the phenotypic level was not easy for our students, and they sometimes combined both levels. Additionally, the use of the category object with regard to the term gene corresponds to the commonly known conception of genes as small particles [8]. Furthermore, we identified some categories that were to be expected, for instance, the category procedure within the conceptions of processes (e.g., transfer of genes). As a result, we argue for the validity of our measure.

Even though we classified our students as novices, we cannot exclude that some students may have previously been taught some aspects of gene technology within other school subjects, for instance, within ethics. However for our target group, syllabuses of ethics do not explicitly focus on gene technology [51]. Finally, we know that our sample size might be considered to be small for quantitative analyses. However, because we combined quantitative analysis with a qualitative one, a limited sample size was necessary. Nevertheless, except for a recently published study ([32]; $N=135)$, we assume our sample size to be larger than the sample sizes from any previous qualitative study (e.g., [26]; $N=90$ ).

4.2. Students' Conceptions in the Context of Gene Technology. With regard to existing conceptions, our results showed that, 
TABLE 6: Common categories of students' conceptions about the terms and processes of gene technology (students' key words for each category within students' quotations in italic letters).

\begin{tabular}{|c|c|c|c|}
\hline Category & $\begin{array}{l}\text { Definition: } \\
\text { conception is connected to }\end{array}$ & $\begin{array}{l}\text { Students' application to } \\
\text { the term/process of ... }\end{array}$ & Sample student's quotation \\
\hline \multirow{5}{*}{ Genotype } & \multirow{5}{*}{ Genotypic level. } & Gene & ... means genetic information ... \\
\hline & & Genetic engineering & ... means genes of the person ... \\
\hline & & Clone & ... exists with the same genes. \\
\hline & & Inheritance of traits & ... means that one has got different genes from his/her parents. \\
\hline & & Change of genotype & ... means that hereditary information will be changed. \\
\hline \multirow{6}{*}{ Phenotype } & \multirow{6}{*}{ Phenotypic level. } & Gene & ... which eye color one has, ... \\
\hline & & Genetic engineering & Traits of plants are being changed. \\
\hline & & Clone & $\begin{array}{l}\text { If a person is cloned he/she looks like the one he/she has been } \\
\text { cloned from. }\end{array}$ \\
\hline & & Inheritance of traits & Maybe the size, the appearance ... is meant here. \\
\hline & & Transfer of genes & If one pass on a trait to his child. \\
\hline & & Change of genotype & $\ldots$ is the chemical change of certain traits of the father. \\
\hline \multirow{5}{*}{ Procedure } & \multirow{5}{*}{ Techniques and/or equipment. } & Genetic engineering & ... means experiments and investigations regarding genes. \\
\hline & & Clone & An animal changed or produced by genetic engineering... \\
\hline & & Inheritance of traits & Specific inherited traits are transmitted by birth... \\
\hline & & Transfer of genes & $\begin{array}{l}\text {... means that one takes somebody's genotype and implements } \\
\text { it on other persons. }\end{array}$ \\
\hline & & Change of genotype & $\begin{array}{l}\text {... means that parts of the genotype are changed by medical } \\
\text { techniques. }\end{array}$ \\
\hline \multirow{4}{*}{ Pedigree } & \multirow{4}{*}{ Words showing relationships. } & Gene & The child of a pair has the genes of his/her parents ... \\
\hline & & Inheritance of traits & ... for example, to have genes from one's father. \\
\hline & & Transfer of genes & The genotype we transfer to our sons or daughters. \\
\hline & & Change of genotype & $\begin{array}{l}\text { For example, if everybody in the family has blond hair and } \\
\text { one child has red hair. }\end{array}$ \\
\hline \multirow{3}{*}{ Valuation } & \multirow{3}{*}{ Value-related aspects. } & Genetic engineering & If one tries to create a perfect human being. \\
\hline & & Clone & $\begin{array}{l}\text {... However, he/she is not human, because he/she was created, } \\
\text { for example, by some scientists or physicists. }\end{array}$ \\
\hline & & Change of genotype & ... is a specific manipulation. \\
\hline \multirow{4}{*}{ Object } & \multirow{4}{*}{ A specific object. } & Gene & $\ldots$ are small cells... \\
\hline & & Clone & A copy of a person or an animal. \\
\hline & & Enzyme & $\ldots$ are corpuscles. \\
\hline & & Change of genotype & If one changes the genes of a human-being. \\
\hline \multirow{2}{*}{ Localization } & \multirow{2}{*}{ A specific localization. } & Gene & ... inside of the person ... \\
\hline & & Enzyme & ... within cells \\
\hline
\end{tabular}

except for the term enzyme, students often have at least one conception of certain terms and processes of gene technology (see Table 4). Usually, they used the same categories to describe their conceptions of different terms and processes (common categories). However, some students (less than $30 \%$ ) extended these categories when needed and additionally used specific categories, perhaps due to the insufficiency of their common categories. For instance, conceptions about the term enzyme were additionally described with the specific category function. This is in line with the recent results of Duncan et al. [32]: when asked for the functions of proteins, their students (7th graders; also novices) commonly mentioned general functions (e.g., "important for promoting health", page 157).
With regard to specific aspects, we focus on all the examined terms and processes, especially any prominent combinations of the categories:

(a) Gene. Many students regarded a gene as a sort of a container. This conception is also known from other subject areas, for instance, within the issue global warming [52]. In this case, students have the conception of the earth as a container that accumulates warmth. In the sense of Lakoff [53], container might be classified as an imaginative conception in contrast to conceptions labeled as basic level structures. According to Gallese and Lakoff [54], students 
TABLE 7: Frequency of common and specific categories of students' conceptions within the terms and processes of gene technology (multiple terms possible).

\begin{tabular}{|c|c|c|c|c|c|c|c|}
\hline \multirow{2}{*}{ Categories of conceptions } & \multicolumn{7}{|c|}{ Terms and processes of gene technology (percentage) } \\
\hline & Gene & Genetic engineering & Clone & Enzyme & Inheritance of traits & Transfer of genes & Change of genotype \\
\hline & \multicolumn{7}{|c|}{ Common categories } \\
\hline Genotype & 28.5 & 80.5 & 38.8 & & 12.4 & & 17.2 \\
\hline Phenotype & 24.3 & 11.7 & 66.9 & & 66.7 & 30.8 & 38.9 \\
\hline Procedure & & 73.4 & 66.8 & & 7.0 & 44.3 & 58.0 \\
\hline Pedigree & 16.0 & & & & 79.1 & 59.7 & 28.0 \\
\hline Valuation & & 18.9 & 6.4 & & & & 32.6 \\
\hline Object & 23.6 & & 92.0 & 55.9 & & & 28.1 \\
\hline \multirow[t]{2}{*}{ Localization } & 20.1 & & & 60.3 & & & \\
\hline & \multicolumn{7}{|c|}{ Specific categories } \\
\hline Container & 18.1 & & & & & & \\
\hline Transmission & 27.1 & & & & & & \\
\hline Individuality & 5.5 & & & & & & \\
\hline Function & & & & 57.4 & & & \\
\hline Source & & & & 11.8 & & & \\
\hline Container & & 30.4 & & & & & \\
\hline
\end{tabular}

develop the latter by individually terming day-today experiences. Imaginative conceptions "are not directly grounded in experience, but (are) drawn on the structure of our experience" [21, page 924]. They provide an understanding of both the day-today world and the scientific world by a metaphoric transference of basic level terms. For instance, filling fluids into a bottle as a part of students' life-world experience may be used as a metaphor for scientifically describing an object (e.g., a cell) filled with hereditary information.

(b) Genetic Engineering. Surprisingly, the category genotype was used mostly to describe conceptions of genetic engineering, often combined with the categories procedure and science. Thus, within our students' conceptions, genetic engineering is a procedural, partially scientific work to be done at the level of the genes, in contrast to the results of Mills Shaw et al. [9, page 1164]. Their 12th graders primarily regard genetic engineering at the phenotypic level. However, we assume that the application of our category genotype within the context of genetic engineering is not based on students' relevant understanding of the term gene: they commonly applied the category phenotype for describing the processes inheritance of traits and change of genotype. Thus; they did not differentiate between the genotypic and the phenotypic level.

(c) Clone. For this term, we found the greatest number of students with existing conceptions. Thereby, they mostly described the term clone as a procedurally caused object which they characterized at the phenotypic level. We assume that the media and popular culture might have influenced our students: in particular, some students mentioned the sheep Dolly [55], and nearly all wrote about copying; perhaps some might have read relevant books for adolescents, for instance, Perfect Copy [56].

(d) Enzyme. Students had the fewest conceptions regarding this term, presumably caused by an actual lack of knowledge. This is in line with the above-mentioned study of Duncan et al. [32]: when asked for the functions of proteins, only a small fraction of their students (11\%) mentioned specific functions (e.g., “enzymes", page 157).

(e) Processes of Gene Technology. Mostly in connection with the processes, we identified the category pedigree, which was also used when describing conceptions of the term gene. The existence of the category pedigree supports the results of Venville et al. [26]. For their students (aged 9 to 15 years), they argued that the students did not understand kinship and inheritance to be genetically based. Our category pedigree points to the ongoing existence of this specific biological conception within our 10th graders. Additionally, our results might corroborate the suggestion of Nelkin and Lindee [29] in which they argued for a cultural anticipation that genes connect parents with offspring.

4.3. Evaluation of Conceptual Change. We successfully administered the questionnaire that we developed by combining the gathered student's alternative conceptions and the scientific conceptions. The constructivist teaching sequence we taught in our lab lesson [45] changed the students' alternative conceptions about the terms and processes of gene technology in favor of the scientific conceptions, both for our subsample of the present study as part of the treatment group of our main study and for the treatment group of our main study as a whole [45]. In contrast to the control group, the effect persisted if the students were first confronted with 
TABLE 8: Multiple-choice questionnaire about students' conceptions in gene technology.

\begin{tabular}{|c|c|c|}
\hline No. & Item: By ... I understand & Categories of students' conception \\
\hline \multirow{5}{*}{ (1) } & Gene & \\
\hline & A trait, for instance, for the color of hair. & Phenotype \\
\hline & A hereditary factor, for instance, for the color of hair (correct). & \\
\hline & A bacterium that transfers traits, for instance, the color of hair. & Object, phenotype, transmission \\
\hline & A cell that contains hereditary factors, for instance, for the color of hair. & Object, genotype, container \\
\hline \multirow{5}{*}{ (2) } & Genetic engineering & \\
\hline & The cloning of genes & Genotype, procedure \\
\hline & The change and transference of genes (correct). & \\
\hline & The change of traits. & Phenotype, procedure \\
\hline & The inheritance of genes. & Genotype \\
\hline \multirow{5}{*}{ (3) } & Clone & \\
\hline & An identical copy of a living being (correct). & \\
\hline & A person with identical signs. & Object, phenotype \\
\hline & An animal with identical signs. & Object, phenotype \\
\hline & An artificially made copy of a living being. & Object, phenotype, procedure \\
\hline \multirow{5}{*}{ (4) } & Enzyme ... a material that & \\
\hline & Is similar to a gene. & Object \\
\hline & Releases a special illness. & Function \\
\hline & Is similar to a hormone. & Object \\
\hline & Facilitates a chemical reaction (correct). & \\
\hline \multirow{5}{*}{ (5) } & Inheritance of traits & \\
\hline & The passing on of acquired traits to the children. & Phenotype, pedigree \\
\hline & The passing on of genetic information with its coded traits to the children (correct). & \\
\hline & The passing on of behavior patterns to the children. & Phenotype, pedigree \\
\hline & The passing on of illnesses. & Phenotype \\
\hline \multirow{5}{*}{ (6) } & Transfer of genotype & \\
\hline & The passing on of the male genotype with sexual intercourse. & Procedure \\
\hline & The passing on of traits of the parents to the children. & Phenotype, pedigree \\
\hline & The fathering of children. & Procedure \\
\hline & The passing on of genotype to the daughters' cells during cell division (correct). & \\
\hline \multirow{5}{*}{ (7) } & Change of genotype & \\
\hline & A process caused by external or internal influence (correct). & \\
\hline & Damage of genotype. & Procedure, valuation \\
\hline & A natural process with the passing on of genotype to the children. & Pedigree, valuation \\
\hline & A natural process during cell division. & Procedure, valuation \\
\hline
\end{tabular}

TABle 9: Medians and scientific conception sum scores in the subsample $(n=25)$ who took part in our constructivist teaching sequence approach over all three test schedules.

\begin{tabular}{lccc}
\hline Score & \multicolumn{3}{c}{ Test date } \\
& Before test & After test & Retention test \\
\hline Median (grouped) & 3.2 & 4.2 & 3.6 \\
25th Percentile & 3.0 & 3.0 & 3.0 \\
75th Percentile & 4.0 & 5.0 & 5.0 \\
\hline
\end{tabular}

their own conceptions and then prompted to discuss them. The resulting cognitive conflict might cause the students to adopt the more plausible scientific conceptions. This is in line with the research that linked cognitive conflicts to positive learning outcome (e.g., [57]) and argued that cognitive conflicts are a prerequisite for conceptual change (e.g., [58]).

\section{Conclusions}

Applying the Model of Educational Reconstruction [20], a necessary prerequisite for a potential conceptual change is the determination of students' conceptions about a specific issue. Our results show that the number of categories students used to describe conceptions about the terms and processes of gene technology was small because some categories were multiply used. However, the metaphorical level we found resembled the results of Ogborn and Martins [59]. Within their study with regard to metaphorical reasoning about 
genetics, primary school teachers very often combined different metaphors, for instance, to describe the term gene technology. The authors argued that this phenomenon is not superfluous but is essential for the teachers to clarify genetic issues, and this may be the case for our students, too. Thus, we do not suggest eliminating this level within teaching. On the other hand, teachers have to precisely describe the term enzyme. Enzymes form the basis for gene technology applications, but many students have no conceptions of them.

Teaching preparation might be facilitated for teachers if they consider selected conceptions in their classrooms and employ a suitable teaching strategy within their lesson. Such a strategy might be to present alternative conceptions on the basis of the constructivist teaching sequence [22] as we did. We recommend considering the categories found in this study and the alternative conceptions they describe during preservice teacher education as well as during in-service teacher professional development, as is already done at our university.

Finally with regard to research in science education, we advocate our methodological approach. We suggest first collecting and then categorizing students' explicitly written alternative conceptions on a given issue. Furthermore, researchers should use these conceptions to develop a quantitative instrument, such as a questionnaire that could potentially monitor students' conceptual change. Applying such an instrument might give insight into the efficiency of an instructional approach that is supposed to foster conceptual change.

\section{Acknowledgments}

The study was funded by the Bavarian State Ministry of the Environment, Public Health and Consumer Protection, the Bavarian State Ministry of Education, and the German Science Foundation (DFG, BO 944/4-4). The authors are very thankful to $M$. Wiseman and $\mathrm{S}$. McGee for the valuable discussion and for reading the text. They are especially grateful to all the participating teachers and students involved in this study.

\section{References}

[1] K. Tanner and D. Allen, "Approaches to biology teaching and learning: understanding the wrong answers-teaching toward conceptual change," Cell Biology Education, vol. 4, pp. 112-117, 2005.

[2] J. D. Novak, A Theory of Education, Cornell University Press, Ithaca, NY, USA, 1977.

[3] R. Driver and J. Easley, "Pupils and paradigms: a review of literature related to concept development in adolescent science students," Studies in Science Education, vol. 5, pp. 61-84, 1978.

[4] H. Helm, "Misconceptions in physics amongst South African students," Physics Education, vol. 15, no. 2, pp. 92-105, 1980.

[5] R. Driver, "Pupils' alternative frameworks in science," European Journal of Science Education, vol. 3, pp. 93-101, 1981.

[6] I. Halloun and D. Hestenes, "The initial knowledge state of college physics students," American Journal of Physics, vol. 53, pp. 1043-1055, 1985.
[7] M. T. H. Chi, J. D. Slotta, and N. De Leeuw, "From things to processes: a theory of conceptual change for learning science concepts," Learning and Instruction, vol. 4, no. 1, pp. 27-43, 1994.

[8] J. Lewis and U. Kattmann, "Traits, genes, particles and information: re-visiting students' understandings of genetics," International Journal of Science Education, vol. 26, no. 2, pp. 195-206, 2004.

[9] K. R. Mills Shaw, K. Van Horne, H. Zhang, and J. Boughman, "Essay contest reveals misconceptions of high school students in genetics content," Genetics, vol. 178, no. 3, pp. 1157-1168, 2008.

[10] B. Born, Learning with Everyday Imaginations, VS Verlag für Sozialwissenschaften, Wiesbaden, Germany, 2007.

[11] D. F. Treagust, "Development and use of diagnostic tests to evaluate students' misconceptions in science," International Journal of Science Education, vol. 10, pp. 159-169, 1988.

[12] A. E. Lawson and L. D. Thompson, "Formal reasoning ability and misconceptions concerning genetics and natural selection," Journal of Research in Science Teaching, vol. 25, pp. 733-746, 1988.

[13] G. J. Posner, K. A. Strike, P. W. Hewson, and W. A. Gertzog, "Accommodation of a scientific conception: toward a theory of conceptual change," Science Education, vol. 66, pp. 211-227, 1982.

[14] K. A. Strike and G. J. Posner, "A revisionist theory of conceptual change," in Philosophy of Science, Cognitive Psychology and Educational Theory and Practise, R. A. Duschl and R. J. Hamilton, Eds., pp. 147-176, University Press, New York, NY, USA, 1992.

[15] M. Limón, "On the cognitive conflict as an instructional strategy for conceptual change: a critical appraisal," Learning and Instruction, vol. 11, no. 4-5, pp. 357-380, 2001.

[16] E. Sander, P. Jelemenská, and U. Kattmann, “Towards a better understanding of ecology," Journal of Biological Education, vol. 40, no. 3, pp. 119-123, 2006.

[17] G. J. Venville and D. F. Treagust, "Exploring conceptual change in genetics using a multidimensional interpretive framework," Journal of Research in Science Teaching, vol. 35, no. 9, pp. 1031$1055,1998$.

[18] R. Duit, H. Gropengießer, and U. Kattmann, “Towards science education research that is relevant for improving practice: the model of educational reconstruction," in Developing Standards in Research on Science Education, H. E. Fischer, Ed., pp. 1-9, Taylor \& Francis, London, UK, 2005.

[19] R. Duit and M. Komorek, "Studies on educational reconstruction of chaos theory," Research in Science Education, vol. 27, no. 3, pp. 339-357, 1997.

[20] U. Kattmann, R. Duit, and G. Gropengießer, "Educational reconstruction. Bringing together issues of scientific clarification and students' conceptions," in What-Why-How? Research in Didaktik of Biology, H. Bayrhuber and F. Brinkman, Eds., pp. 253-262, IPN, Kiel, Germany, 1998.

[21] T. Riemeier and H. Gropengießer, "On the roots of difficulties in learning about cell division: process-based analysis of students' conceptual development in teaching experiments," International Journal of Science Education, vol. 30, no. 7, pp. 923939, 2008.

[22] R. Driver, "Changing conceptions," in Adolescent Development and School Science, P. S. Adey, J. Bliss, J. Head, and M. Shayer, Eds., pp. 79-104, The Falmer Press, New York, NY, USA, 1989.

[23] R. Driver and V. Oldham, "A constructivist approach to curriculum development in science," Studies in Science Education, vol. 13, pp. 105-122, 1985. 
[24] D. Krüger, J. Fleige, and T. Riemeier, "How to foster an understanding of growth and cell division," Journal of Biological Education, vol. 40, no. 3, pp. 135-140, 2006.

[25] R. Duit, “Bibliography: Students' and teachers' conceptions and science education (STCSE)," University of Kiel, Kiel, Germany, 2009, http://www.ipn.uni-kiel.de/aktuell/stcse/stcse.html.

[26] G. Venville, S. J. Gribble, and J. Donovan, "An exploration of young children's understandings of genetics concepts from ontological and epistemological perspectives," Science Education, vol. 89, no. 4, pp. 614-633, 2005.

[27] M. Stolarsky Ben-Nun and A. Yarden, "Learning molecular genetics in Teacher-Led Outreach Laboratories," Journal of Biological Education, vol. 44, no. 1, pp. 19-25, 2009.

[28] K. Springer, "How a naïve theory of biology is acquired," in Children's Understanding of Biology and Health, M. Siegel and C. C. Peterson, Eds., pp. 45-70, Cambridge University Press, Cambridge, UK, 1999.

[29] D. Nelkin and M. S. Lindee, The DNA Mystique: The Gene as Cultural Icon, University of Michigan Press, Michigan, Mich, USA, 1999.

[30] J. Lewis, J. Leach, and C. Wood-Robinson, "All in the genes? Young people's understanding of the nature of genes," Journal of Biological Education, vol. 34, no. 2, pp. 74-79, 2000.

[31] R. G. Duncan and B. J. Reiser, "Reasoning across ontologically distinct levels: students' understandings of molecular genetics," Journal of Research in Science Teaching, vol. 44, no. 7, pp. 938959, 2007.

[32] R. G. Duncan, H. B. Freidenreich, C. A. Chinn, and A. Bausch, "Promoting middle school students' understandings of molecular genetics," Research in Science Education, vol. 41, no. 2, pp. 147-167, 2010.

[33] C. Y. Tsui and D. F. Treagust, "Understanding genetics: analysis of secondary students' conceptual status," Journal of Research in Science Teaching, vol. 44, no. 2, pp. 205-235, 2007.

[34] S. Vosniadou, C. Ioannides, A. Dimitrakopoulou, and E. Papademetriou, "Designing learning environments to promote conceptual change in science," Learning and Instruction, vol. 11, no. 4-5, pp. 381-419, 2001.

[35] M. H. Chiu, C. C. Chou, and C. J. Liu, "Dynamic processes of conceptual change: analysis of constructing mental models of chemical equilibrium," Journal of Research in Science Teaching, vol. 39, no. 8, pp. 688-712, 2002.

[36] M. S. Jensen and F. N. Finley, "Teaching evolution using historical arguments in a conceptual change strategy," Science Education, vol. 79, pp. 147-166, 1995.

[37] N. M. Mbajiorgu, N. G. Ezechi, and E. C. Idoko, "Addressing nonscientific presuppositions in genetics using a conceptual change strategy," Science Education, vol. 91, no. 3, pp. 419-438, 2007.

[38] C. Y. Tsui and D. F. Treagust, "Genetics reasoning with multiple external representations," Research in Science Education, vol. 33, no. 1, pp. 111-135, 2003.

[39] Bavarian Ministry of Education, "Education in Bavaria," 2011, http://www.km.bayern.de/education-in-bavaria.html.

[40] Bavarian Ministry of Education, "School and education in Bavaria 2009. Statistical overview," Statistische Übersichten. München, Germany, 2009, http://www.verwaltung.bayern.de/ Anlage3998543/DokumentationSchuleundBildunginBayern2009.pdf.

[41] Bavarian Ministry of Education, Syllabus Bavarian Hauptschule, chapter III, part I grade 9, Kastner, Wolnzach, Germany, 2004.
[42] Bavarian Ministry of Education, Syllabus Realschule: biology grade 10, Maiss, München, Germany, 2001.

[43] Bavarian Ministry of Education, Syllabus Gymnasium G8, Kastner, Wolnzach, Germany, 2004.

[44] V. N. Lunetta, "The school science laboratory: historical perspectives and contexts for contemporary teaching," in International Handbook of Science Education, B. J. Fraser and K. J. Tobin, Eds., pp. 249-262, Kluver Academic Publishers, London, UK, 1998.

[45] G. Franke and F. X. Bogner, "Conceptual change in students' molecular biology education: tilting at windmills?" Journal of Educational Research, vol. 104, no. 1, pp. 7-18, 2011.

[46] P. Mayring, "Qualitative content analysis," Forum Qualitative Social Research, vol. 1, pp. 1-20, 2000.

[47] J. Cohen, "Weighted kappa: nominal scale agreement provision for scaled disagreement or partial credit," Psychological Bulletin, vol. 70, no. 4, pp. 213-220, 1968.

[48] R. M. Wolf, "Rating scales," in Educational Research, Methodology and Measurement: An International Handbook, J. P. Keeves, Ed., pp. 958-965, Elsevier, Oxford, UK, 1997.

[49] K. V. King, D. A. Gardner, S. Zucker, and M. A. Jorgensen, The Distractor Rationale Taxonomy: Enhancing Multiple-Choice Items in Reading and Mathematics, Pearson, San Antonio, Tex, USA, 2004.

[50] U. Kattmann, V. Frerichs, and M. Gluhodedow, "Genes are characterless," Der Mathematische und Naturwissenschaftliche Unterricht, vol. 58, pp. 324-330, 2005.

[51] Bavarian Ministry of Education, Syllabus Realschule: profile of the subject ethics, Maiss, München, Germany, 2001.

[52] K. Niebert, "I would like it if it would get somewhat warmer where we are," Erkenntnisweg Biologiedidaktik, vol. 7, pp. 23-38, 2008.

[53] G. Lakoff, Women, Fire, and Dangerous Things: What Categories Reveal About the Mind, University of Chicago Press, Chicago, Ill, USA, 1987.

[54] V. Gallese and G. Lakoff, "The brain's concepts: the role of the sensory-motor system in conceptual knowledge," Cognitive Neuropsychology, vol. 22, no. 3-4, pp. 455-479, 2005.

[55] I. Wilmut, A. E. Schnieke, J. McWhir, A. J. Kind, and K. H. S. Campbell, "Viable offspring derived from fetal and adult mammalian cells," Nature, vol. 385, pp. 810-813, 1997.

[56] A. Eschbach, Perfect Copy. (The Second Creation), Arena, Würzburg, Germany, 2002.

[57] L. Mason, "Responses to anomalous data on controversial topics and theory change," Learning and Instruction, vol. 11, no. 6, pp. 453-483, 2001.

[58] S. Kang, L. C. Scharmann, and T. Noh, "Reexamining the role of cognitive conflict in science concept learning," Research in Science Education, vol. 34, no. 1, pp. 71-96, 2004.

[59] J. Ogborn and I. Martins, "Metaphorical understandings and scientific ideas," International Journal of Science Education, vol. 18, no. 6, pp. 631-652, 1996. 

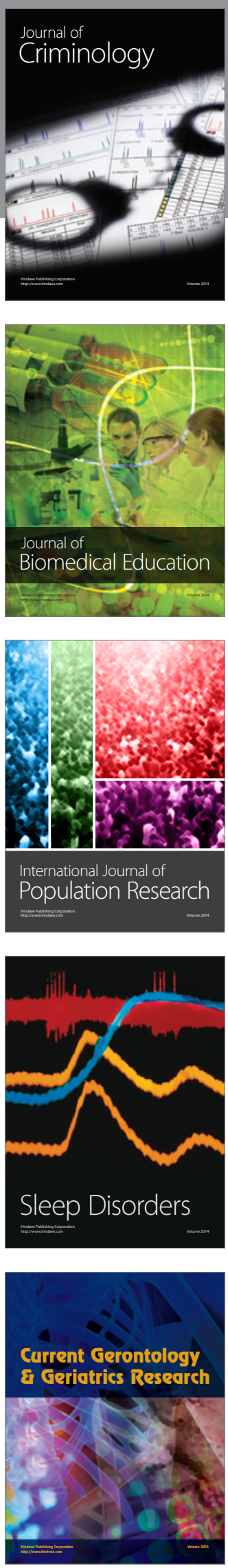
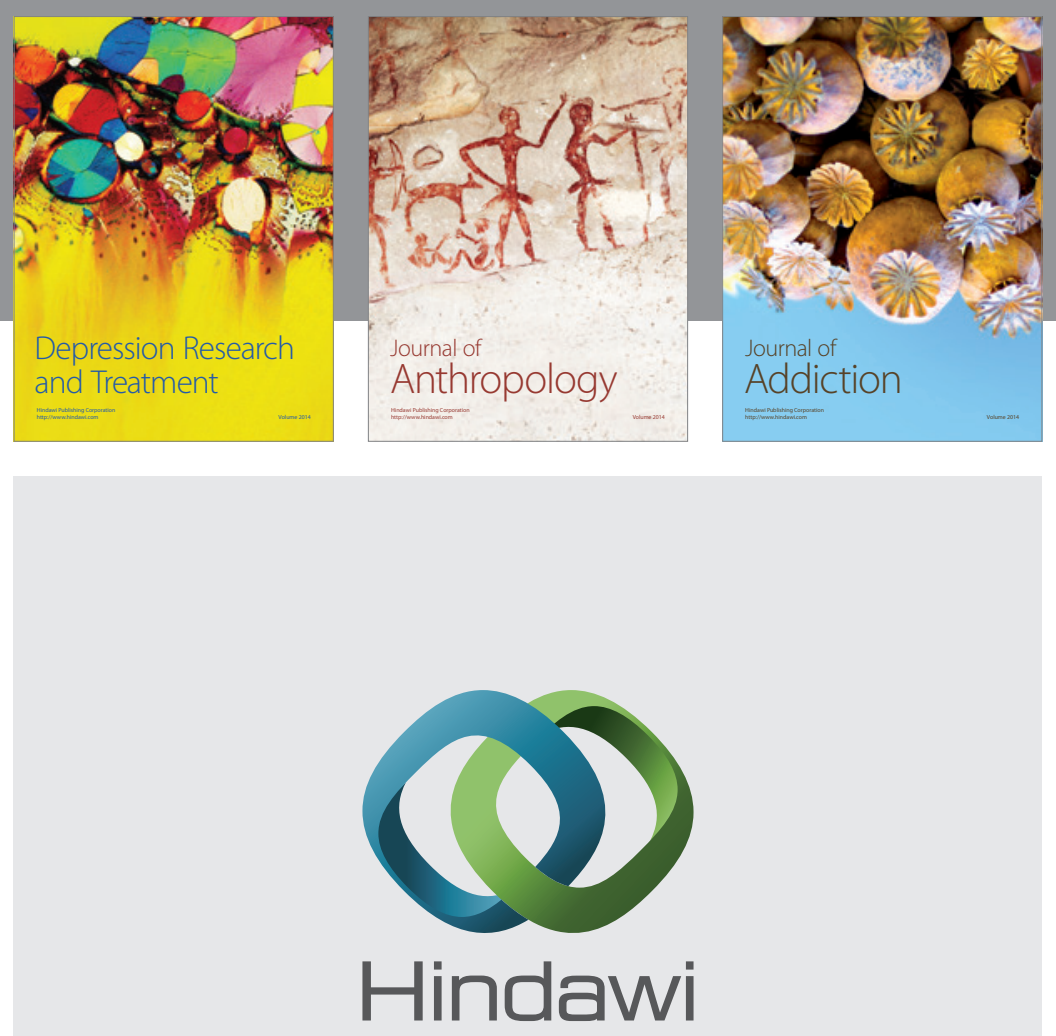

Submit your manuscripts at

http://www.hindawi.com

Child Development Research
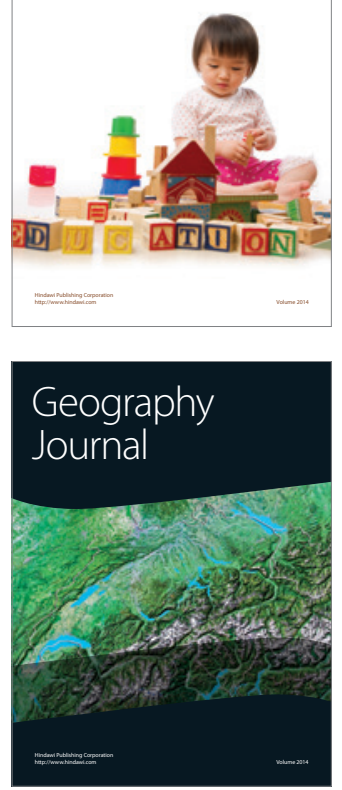

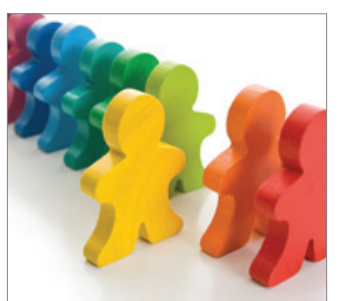

Autism

Research and Treatment
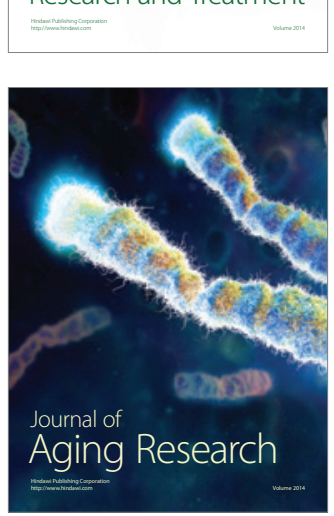
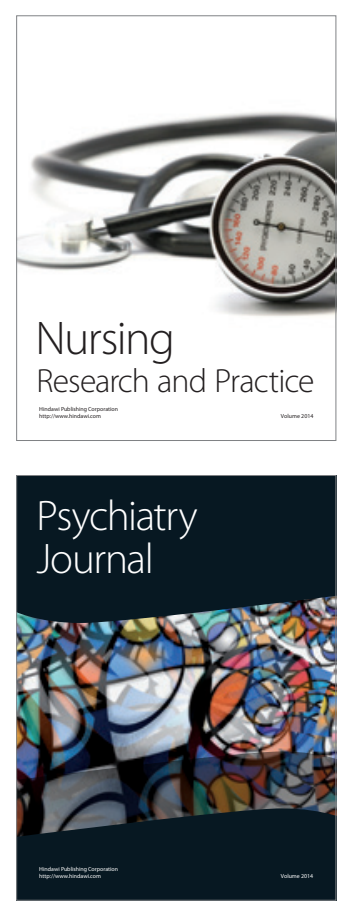
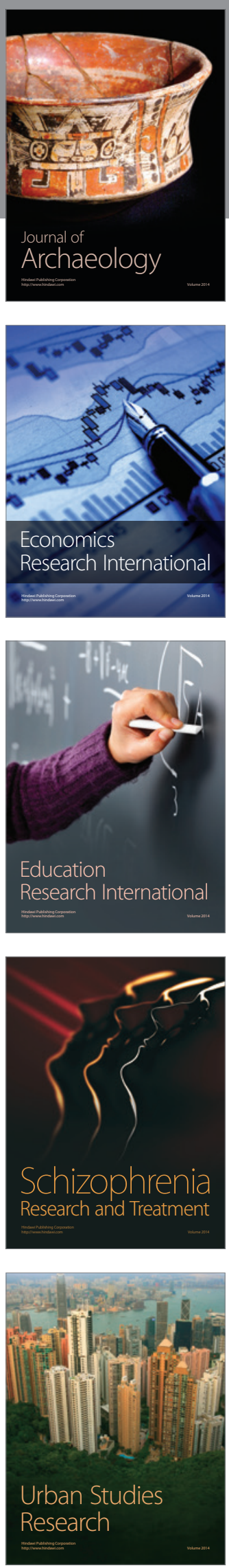